\title{
PENGARUH KOMPETENSI KEPRIBADIAN GURU TERHADAP MOTIVASI BELAJAR PESERTA DIDIK MTSN 2 BONE KABUPATEN BONE
}

\author{
Arisman \\ Abd. Rahman Getteng \\ Nuryamin \\ Pascasarjana UIN Alauddin Makassar \\ Jln. Sultan Alauddin No. 36 Samata Gowa \\ Email : Arismankhilafah@gmail.com
}

\begin{abstract}
Abstrak: Pokok masalah penelitian ini adalah bagaimana pengaruh kompetensi kepribadian dan profesional guru terhadap motivasi belajar peserta didik MTsN 2 Bone? Pokok masalah tersebut kemudian dijabarkan ke dalam beberapa 3 sub masalah penelitian, yaitu: (1) Bagaimana kompetensi kepribadian guru MTsN 2 Bone? (2) Bagaimana motivasi belajar peserta didik MTsN 2 Bone? (3) Seberapa besar pengaruh kompetensi kepribadian guru terhadap motivasi belajar peserta didik MTsN 2 Bone? Hasil penelitian ini menunjukkan: (1) Kompetensi kepribadian guru MTsN 2 Bone berada pada kategori sedang, dengan frekuensi 10 dan persentase $55 \%$ dengan nilai rata-rata 76,01 dari skor idel 80. (2) Motivasi belajar peserta didik MTsN 2 Bone berada pada kategori sedang, dengan frekuensi 54 dengan persentase $64,30 \%$ dengan nilai ratarata 78,55 dari skor ideal 92. (3) Terdapat pengaruh kompetensi kepribadian guru terhadap motivasi belajar peserta didik sebesar $50.3 \%$. Implikasi penelitian ini adalah bahwa kompetensi kepribadian guru lebih ditingkatkan lagi. Kompetensi kepribadian guru dapat terhadap motivasi belajar peserta didik di MTsN 2 Bone. Sebab seorang guru memegang kunci utama dalam menstimulus motivasi belajar peserta didik.
\end{abstract}

Keywords: Kompetensi Kepribadian, dan Motivasi Belajar

\section{PENDAHULUAN}

Semua orang membutuhkan pendidikan, sebab pendidikan tidak akan pernah bisa dipisahkan dengan kehidupan manusia, baik itu dalam lingkup formal, informal maupun nonformal. Keluarga merupakan lembaga pertama tempat seorang anak mendapat pendidikan, dari orang tua kepada anaknya. Ketika mereka tumbuh dewasa dan memiliki keluarga mereka juga akan memberikan didikan kepada anak-anaknya. Begitu pula di lingkungan sekolah dan perguruan tinggi, guru dan dosen akan senantiasa memberikan didikan kepada siswa dan mahasiswanya. Pendidikan membantu peserta didik dalam mencapai kedewasaanya melalui pengembangan diri, pengembangan semua potensi, 
kecakapan serta karakteristik pribadinya ke arah yang lebih positif, guna terciptanya individu-individu yang cerdas akan zikir dan fikirnya.

Pendidikan adalah usaha sadar dan terencana untuk mewujudkan suasana belajar dan proses pembelajaran agar peserta didik secara aktif mengembangkan potensi dirinya untuk memiliki kekuatan spiritual keagamaan, pengendalian diri, kepribadian, kecerdasan, akhlak mulia, serta keterampilan yang diperlukan dirinya, masyarakat bangsa dan negara. ${ }^{1}$ Proses pendidikan menjadi salah satu hal yang sangat berperan penting dalam meningkatkan kualitas sumber daya manusia.

Dalam Islam pendidikan pada dasarnya adalah pendidikan yang bertujuan untuk membentuk pribadi muslim yang komperhensif yaitu adanya keseimbangan hubungan dengan Allah swt. manusia dengan alam serta mengembangkan seluruh potensi manusia baik yang berbentuk jasmani maupun rohani. ${ }^{2}$ Ahmad Tafsir menjelaskan bahwa pendidikan Islam adalah usaha sadar dan terencana yang terstruktur secara sistematis yang pengimplementasiannya tidak hanya memanusiakan manusia tetapi lebih jauh lagi agar manusia menyadari posisinya sebagai khalifatullah fil ardhi, yang pada gilirannya akan semakin meningkatkan dirinya untuk menjadi manusia yang bertakwa, beriman, berilmu dan beramal salih dalam konteks mendekatkan diri kepada Allah swt.

Guru merupakan salah satu komponen yang sangat penting dalam proses pembelajaran, tentunya seorang guru harus memiliki kompetensi yang bisa menentukan keberhasilan pembelajaran, karena fungsi utama guru adalah merancang, mengelola, melaksanakan, dan mengevaluasi pembelajaran. Selain itu, kedudukan guru dalam kegiatan belajar mengajar juga sangat strategis dan menentukan. ${ }^{3}$

Kedudukan guru sangatlah urgen dalam dunia pendidikan sebab guru adalah sosok yang diberikan amanah oleh orang tua peserta didik untuk mendidik peserta didik agar menjadi manusia seutuhnya, sebagi yang diberi amanah tentunya seorang guru memiliki peran serta fungsi bukan hanya sebagai pengajar dan pendidik namun juga sebagai orang tua kedua bagi peserta didik. Guru yang merupakan orang tua bagi peserta didiknya tentu harus mengarahkan peserta didik untuk mencapai prestasi di dunia dan akhirat serta menjaganya untuk tidak berbuat sebuah kesalahan. Sebagaimana firman Allah swt. dalam QS alTahrim/66: 6:

${ }^{1}$ Republik Indonesia, Undang-Undang RI Nomor 20 Tahun 2003, tentang Sistem Pendidikan Nasional, Bab I Pasal 1.

${ }^{2}$ Haidar Putra Dauly, Pendidikan Islam dalam Sistem Pendidikan Nasional di Indonesia (Jakarta: Prenada Media, 2004), h. 31.

${ }^{3}$ Abd. Rahman Getteng, Menuju Guru Profesional dan Ber-Etika (Cet. VIII; Yogyakarta: Graha Guru, 2012), h. 2. 


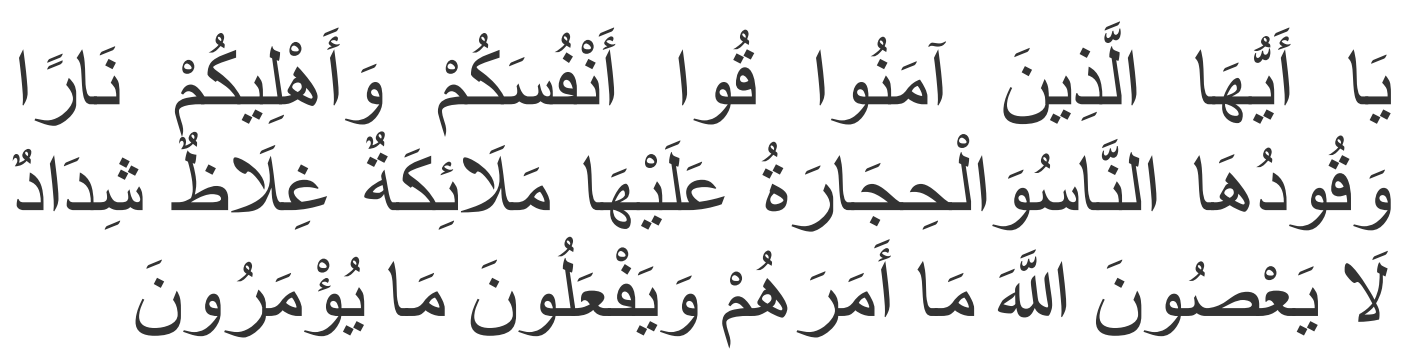

Terjemahnya:

Hai orang-orang yang beriman, peliharalah dirimu dan keluargamu dari api neraka yang bahan bakarnya adalah manusia dan batu; penjaganya malaikat-malaikat yang kasar, keras, dan tidak mendurhakai Allah terhadap apa yang diperintahkan-Nya kepada mereka dan selalu mengerjakan apa yang diperintahkan. ${ }^{4}$

Sebagaimana ayat di atas, maka seorang guru haruslah memelihara dirinya dari api neraka, hal ini mengindikasikan bahwa seorang guru harus memiki kepribadian yang baik yang tercermin dari akhlaknya, bagitu juga dia mesti memelihara peserta didiknya dari api neraka dengan senantiasa mengajarkan kepada hal-hal yang baik dan mencegahnya dari perbuatan yang buruk. Dengan demikian seorang guru diharapkan menampilkan sosok yang dapat ditiru sebelum menyuruh sesuatu untuk dilakukuan, serta terget seorang guru dalam mengajar bukan hanya untuk mencapai kesuksesan di dunia tapi orientasinya lebih jauh lagi yakni mengantarkan peserta didiknya untuk mencapai kesuksesan akhirat.

Disamping sebagai pendidik, seorang guru juga dituntuk untuk memiliki pengetahuan yang memadai yang mampu menjawab problematika pembelajaran peserta didik, seorang guru haruslah mampu memiliki wawasan keilmuan yang mampu menghantarkan peserta didik menjadi pribadi yang cerdas secara emotional maupun spritual, mampu membedakan yang benar dan yang salah. Guru yang cerdas tentulah menjadi panutan serta tuntunan oleh siapa saja terlebih lagi anak didiknya, kecerdasan seorang guru akan tercermin dari akhlaknya dalam menjalankan tugas keprofesionalannya. Guru memiliki tugas berat yang harus diembannya, dia harus cerdas (berilmu) dan memiliki kepribadian (akhlak) yang pantas untuk diteladani, sebab seorang guru adalah pewaris para nabi.

Berkaitan dengan kompetensi guru, pemerintah telah merumuskan 4 jenis kompetensi guru sebagaimana tercantum dalam Undang-Undang Guru dan Dosen No. 14 Tahun 2005 disebutkan bahwa kompetensi guru meliputi kompetensi pedagogik, keperibadian, sosial, dan profesional yang diperoleh melalui pendidikan profesi. ${ }^{5}$ Profesi guru sangat identik dengan tugas mendidik,

${ }^{4}$ Kementerian Agama RI, Al-Qur'ān dan Tafsirnya, Jilid X (Cet. III; Jakarta: Dapartemen Agama RI, 2009) h. 203.

${ }^{5}$ Republik Indonesia, Undang-Undang tentang Guru dan Dosen Nomor 14 Tahun 2005 (Cet. IX; Jakarta: Sinar Grafika, 2016), h. 9. 
mengajar, membimbing, mengarahkan, melatih, menilai serta mengevaluasi peserta didik.

Guru merupakan pemimpin dalam pendidikan bahkan menjadi sentral pendidikan yang mestinya ditiru dan dijadikan panutan oleh anak didiknya. Baik buruknya hasil didikan tersebut tergantung pada contoh yang diberikan sang guru sebagai sosok teladan yang ditiru, seperti sebuah petuah mengatakan bahwa guru kencing berdiri murid kencing berlari. Melihat peran guru tersebut, sudah menjadi kemutlakan bahwa guru harus memiliki integritas dan kepribadian yang baik dan benar, sekaligus memiliki wawasan yang luas terkait dengan pendidikan. Hal ini sangat mendasar karena tugas guru bukan hanya mengajar tetapi juga menanamkan nilai-nilai dasar pegembangan karakter siswa.

Berkenaan dengan kompetensi kepribadian dan keprofesionalan, hal ini menjadi kompetensi yang sangat penting yang mesti dimiliki oleh seorang guru. Dalam dunia pendidikan guru merupakan sentral pendidikan bagi peserta didik, baik dan buruknya perilaku seorang guru sangat berpengaruh bagi peserta didik. Sebagai sentral pendidikan seorang guru tentunya harus dibekali dengan sikap profesionalisme, mempunyai wawasan pengetahuan terhadap bidang pelajaran yang diajarkan dan tentunya memiliki keperibadian yang bisa diteladani oleh peserta didik.

Dewasa ini, mutu pendidikan di Indonesia belum seperti yang diharapkan. Menurut Sukmadinata "Selain masih kurangnya sarana dan fasilitas belajar, adalah faktor guru. Pertama, Guru belum bekerja sungguh-sungguh. Kedua, kemampuan profesional guru masih kurang". 6 Keprofesionalan seorang guru menjadi salah satu persoalan yang dapat menentukan merosotnya pendidikan. Hal ini dapat dilihat dengan banyaknya tenaga pendidik atau guru yang tidak kompeten serta tidak memiliki kualifikasi sebagai seorang guru dengan mata pelajaran yang diajarkan sehingga pembelajaran tidak berjalan dengan baik sebagaimana semestinya.

Di lapangan terlihat banyak guru yang belum memenuhi standar kompetensi sebagaimana yang diharapkan. Pertama, guru tidak memiliki pengetahuam dan keterampilan mengelola peserta didik. Misalnya banyak kasus guru memberikan hukuman yang berlebihan terhadap peserta didiknya, bahkan sampai melukai. Kedua, kepribadian guru masih labil. Misalnya, guru menodai siswanya sendiri, sehingga guru seperti ini sulit dijadikan teladan oleh para siswa dan masyarakat. Ketiga, kemampuan pendidik sebagai bagian dari masyarakat masih rendah. Misalnya, guru tidak mampu menulis karya ilmiah sebagai bagian komunikasi dengan masyarakat, dan buruknya hubungan guru dengan peserta didik dan masyarakat sehingga guru tidak mengetahui problem yang dihadapi

\footnotetext{
${ }^{6}$ N. Sy. Sukmadinata, Pengembangan Kurikulum: Teori dan Praktik(Cet. VIII; Bandung: Rosdakarya, 2006), h. 203.
} 
peserta didiknya, apalagi masyarakat sekitarnya. Keempat, penguasaan guru terhadap materi pembelajaran masih dangkal. Misalnya, guru kesulitan dalam menerapkan materi yang diajarkan dengan kehidupan siswanya sehari-hari, ${ }^{7}$ bahkan ada guru hanya sebatas menyampaikan materi tanpa berpikir apakah peserta didiknya faham atau tidak yang jelas dia sudah menunaikan kewajibannya di kelas yakni mengajar.

Kepribadan dan keprofesionalan guru dalam mengelola kelas, dapat mempengaruhi kepribadian peserta didik seperti motivasi, disiplin, tingkah laku, prestasi dan hasrat untuk belajar pada siswa. Kemampuan untuk menilai diri sendiri dan mengendalikan diri serta memecahkan berbagai masalah yang dialami oleh peserta didik harus dimiliki oleh seorang guru. Hari ini masih dapat ditemukan guru yang bermasalah dalam menjalankan tugasnya. Padahal seorang guru harus dapat menampilkan kepribadian yang baik di depan peserta didiknya baik dalam proses belajar mengajar maupun dalam kehidupan sehari-hari. Masih ada sebagian guru yang mengajar di sekolah belum dapat menunjukkan karakteristik kepribadian dan keprofesionalannya. Seperti pembawaan yang kurang ramah, kurang kreatif, sering marah, asal masuk kelas, masuk kelas sering terlambat dan bahkan ada guru yang terkesan cuek yang tidak mau tau dengan keadaan dan persoalan yang dihadapi oleh peserta didik, padahal semua ini akan mempengaruhi motivasi belajar mereka.

Aspek motivasi merupakan hal yang sangat penting dalam keseluruhan proses belajar mengajar sebab hal tersebut dapat mendorong peserta didik untuk melakukan berbagai aktivitas-aktivitas tertentu yang berpengaruh dalam peroses pengembangan kepribadiannya guna mencapai prestasi belajarnya. Tanpa adanya motivasi seorang peserta didik tentu tidak akan berminat dalam belajar apalagi mencapai prestasi dalam belajar. Jadi jelas bahwa sebuah motivasi sangatlah diperlukan dalam proses pembelajaran yang menjadi motor penggerak bagi peserta didik dalam melakukan aktivitas belajarnya.

Motivasi belajar peserta didik meningkat ketika para guru menciptakan lingkungan belajar yang menarik dengan menyajikan karakteristik pribadi yang peserta didik anggap menarik, sabar, serta mengarahkan siswa untuk tahu tujuan materi pelajaran yang berusaha dipenuhi dan membuat pelajaran berharga untuk dipelajari, dan yang paling penting lainnya yakni patut untuk ditiru bukan hanya mengandalakan aspek ceramah saja namun juga memberikan contoh melalui sikapnya sebagi seorang guru. ${ }^{8}$ Apabila hal ini diabaikan maka sangat mungkin proses pembelajaran tidak akan berjalan dengan baik.

${ }^{7}$ Jejen Musfah, Peningkatan Kompetensi Guru Melalui Pelatihan dan Sumber Belajar Teori dan Peraktik (Cet. II; Jakarta: Kencana, 2012), h. 7.

${ }^{8}$ Syarif Bahri Djamarah, Perestasi Belajar dan Kompetensi Mengajar (Surabaya: Usaha Nasional, 2013), h. 43. 
MTsN 2 Bone memiliki misi untuk menciptakan peserta didik yang memiliki akhlakul kharimah. Maka dari itu seorang guru sangat berperan penting dalam mewujudkan misi tersebut. Guru sebagai pendidik sekaligus figur di dalam maupun di luar ruangan kelas, diharapkan bisa memberikan pembelajaran yang bermanfaat serta menjadi tedalan bagi peserta didik dalam meningkatkan motivasi belajar guna mencapai tujuan pembelajar. Maka dari itu penulis memilih untuk mengangkat judul tesisi "Pengaruh Kompetensi Keperibadian dan Profesional Guru terhadap Motivasi Belajar Peserta Didik MTsN 2 Bone" sebagai bahan penelitian.

Adapun yang menjadi pokok masalah dalam penelitan ini adalah bagaimana pengaruh kompetensi keperibadian guru terhadap motivasi belajar siswa MTsN 2 Bone?

\section{TINJAUAN TEORETIS}

\section{Konsep Kompetensi Kepribadian}

Kompetensi guru sebagaimana dalam Undang-Undang Nomor 14 Tahun 2005 tentang Guru dan Dosen pasal 1 ayat 10 mengatakan, kompetensi adalah seperangkat pengetahuan, keterampilan dan perilaku yang harus dimiliki, dihayati, dan dikuasai oleh guru atau dosen dalam melaksanakan tugas keprofesionalanya. ${ }^{9}$ Keluarnya UU No. 14 Tahun 2005 tentang guru dan dosen ini memberikan gambaran bahwa pekerjaan seorang guru adalah pekerjaan profesional yang harus memiliki seperangkat kompetensi dalam menjalankan tugas sehari-hari sebagai tenaga pendidik.

Menurut Jamil Suprihatiningrum kompetensi kepribadian guru adalah kemampuan personal yang mencerminkan kepribadian yang mantap, stabil, dewasa, arif, dan berwibawah, menjadi teladan bagi siswa, dan berakhlak mulia. ${ }^{10}$ Kompetensi kepribadian tersebut seharusnya melekat pada diri guru dan mencerminkan ciri khas dari sosok seorang guru.

Chaerul Rochman mengatakan bahwa kompetensi kepribadian guru adalah kemampuan personal yang mencerminkan kepribadian yang mantap, stabil, dewasa, arif dan berwibawa, menjadi teladan bagi peserta didik dan berakhlak mulia. Kemampuan personal guru, mencakup 1) penampilan sikap yang positif terhadap keseluruhan tugasnya sebagai guru, dan terhadap keseluruhan situasi pendidikan beserta unsur-unsurnya, 2) pemahaman, penghayatan dan penampilan nilai-nilai yang seyogyanya dianut oleh seorang guru, 3) kepribadian, nilai, sikap

\footnotetext{
${ }^{9}$ Republik Indonesia, Undang-Undang tentang Guru dan Dosen Nomor 14 Tahun 2005
} (Cet. IX; Jakarta: Sinar Grafika, 2016), h. 4.

${ }^{10}$ Jamil Suprihatiningrum, Guru Profesional Pedoman Kinerja, Kualifikasi, \& Kompetensi Guru(Cet. II; Jogjakarta: Ar Ruzz Media, 2014) h. 106. 
hidup ditampilkan dalam upaya untuk menjadikan dirinya sebagai panutan dan teladan bagi para peserta didiknya. ${ }^{11}$

Berdasarkan beberapa pendapat tersebut penulis berkesimpulan bahwa seorang guru harus memiliki kemampuan seperti berakal cerdas, beragama, punya kepandaian dalam mendidik akhlak, cakap dalam mendidik anak, beribawa dan penuh kesungguhan, tidak bermuka masam dan statis, sopan santun, bersih dan suci. Mendidik anak bukanlah suatu pekerjaan yang mudah apalagi dilakukan secara serampangan akan tetapi merupakan pekerjaan yang membutuhkan pengetahuan tentang ilmu pendidikan, mencintai anak didik, senantiasa intens dalam hal mendidik, ikhlas dalam beramal, serta mempelajari kebiasaan dan watak anak didiknya.

Secara rinci subkompetensi tersebut dapat dijabarkan sebagai berikut:

a. Kepribadian yang Mantap dan Stabil

Indikator dari kepribadian yang mantap dan stabil yaitu bertindak sesuai dengan norma hukum, bertindak sesuai norma sosial, bangga sebagai guru profesional, dan memiliki konsistensi dalam bertindak sesuai norma yang berlaku dalam kehidupan. Pribadi yang mantap berarti seorang guru tersebut memiliki suatu keperibadan yang tidak tergoyahkan (tetap teguh dan kuat dalam pendiriannya). Sedangkan pribadi yang stabil merupakan suatu kepribadian yang kokoh, jika kita telaah dari segi arti bahasanya pribadi stabil ini sama halnya dengan pribadi mantap.

Agar dapat melaksanakan tugasnya dengan baik, guru harus memiliki kepribadian yang mantap dan stabil. Hal ini penting, karena banyak masalah pendidikan yang disebabkan oleh faktor kepribadian guru yang kurang mantap dan kurang stabil. Kondisi kepribadian yang demikian sering membuat guru melakukan tindakan-tindakan yang tidak profesional, tidak terpuji, bahkan tindakan-tindakan yang bisa menciderai citra dan martabat guru. Kepribadian yang mantap dan stabil ini menekankan pada tiga hal yang menjadi landasan kepribadiannya, yakni: kebenaran, tanggung jawab, dan kehormatan. Dalam menghadapi permasalahan seorang guru harus mampu meredam emosi dan dapat menyelesaikan dengan tenang sehingga dapat menjaga kehormatannya sebagai guru. ${ }^{12}$ Jika tidak dapat mengendalikan emosi dan mudah marah akan membuat peserta didik takut, dan ketakutan mengakibatkan kurangnya minat untuk mengikuti pelajaran serta rendahnya konsentrasi, karena ketakutan menimbulkan

\footnotetext{
${ }^{11}$ Chaerul Roochman dan Heri Gunawan, Pengembangan Kompetensi Keperibadian Guru; Menjadi Guru yang Dicintai dan Diteladani oleh Siswa (Cet. I; Bandung: Nuansa Cendikia, 2011), h. 29.

${ }^{12}$ E. Mulyasa, Standar Kompetensi dan Sertifikasi Guru (Bandung: PT. Remaja Rosdakarya, 2007) h. 121.
} 
kekhawatiran untuk dimarahi dan membelokkan konsentrasi peserta didik, sehingga motivasi untuk belajarpun menurun.

b. Kepribadian yang Dewasa

Indikator dari kepribadian yang dewasa yaitu menampilkan kemandirian bertindak sebagai pendidik dan memiliki etos kerja yang tinggi. Guru sebagai pribadi, pendidik, pengajar dan pembimbing dituntuk untuk memiliki kematangan atau kedewasaan pribadi, serta kesehatan jasmani dan rohani. ${ }^{13}$

Kedewasan guru tercermin dari kestabilan emosinya. Untuk itu, diperlukan latihan mental agar guru mudah terbawa emosi. Sebab, jika guru marah akan mengakibatkan siswa takut. Ketakutan itu sendiri berdampak pada turunnya minat siswa untuk mengikuti proses pembelajaran, serta dapat menganggu konsentrasi belajarnya. $^{14}$

Pribadi yang dimiliki seorang guru bisa menjadikan peserta didik merasa terlindungi, diayomi, dan dibimbing dalam proses belajar dan mengajar. Dengan terjalinnya keakraban antara guru dengan peserta didik maka proses belajar mengajar akan berjalan dengan lancar.

c. Kepribadian yang Arif

Indikator dari kepribadian yang arif yaitu: menampilkan tindakan yang didasarkan pada kemanfaatan peserta didik, sekolah dan masyarakat serta menunjukkan keterbukaan dalam berfikir dan bertindak. Dalam pendidikan, mendisiplinkan peserta didik harus dimulai dengan peribadi guru yang disiplin, arif, dan berwibawah. Banyak perilaku peserta didik yang menyimpang bahkan bertentangan dengan moral yang baik, seperti merokok, rambut gondrong, rambut disemir, membolos, tidak mengerjakan tugas, berkelahi, tawuran, melawan guru dan masih banyak lagi. Dengan kata lain, masih banyak peserta didik yang tidak disiplin dan hal ini dapat menghambat jalannya pembelajaran. Kondisi tersebut menuntut guru untuk bersikap disiplin, arif, dan berwibawah dalam segala tindakan dan perilakunya, serta senantiasa mendisiplinkan peserta didik agar dapat meningkatkan kualitas pembelajaran. ${ }^{15}$

Kepribadian yang arif ditunjukkan melalui tindakan yang bermanfaat bagi peserta didik, sekolah, dan masyarakat serta menunjukkan keterbukaan dalam berpikir dan bertindak. ${ }^{16}$ Tugas guru dalam pembelajaran tidak hanya menyampaikan materi pembelajaran saja, namun lebih dari itu guru harus senantiasa mengawasi perilaku peserta didik, terutama pada jam-jam sekolah, agar

\footnotetext{
${ }^{13}$ E. Mulyasa, Standar Kompetensi dan Sertifikasi, h. 123.

${ }^{14}$ Jamil Suprihatiningrum, Guru Profesional Pedoman Kinerja, Kualifikasi,\& Kompetensi Guru, h. 106-107.

${ }^{15}$ E. Mulyasa, Standar Kompetensi dan Sertifikasi, h. 122-126.

${ }^{16}$ Jamil Suprihatiningrum, Guru Profesional Pedoman Kinerja, Kualifikasi, \& Kompetensi Guru, h. 107
} 
tidak terjadi penyimpangan prilaku yang tidak disiplin. Bentuk perwujudan dalam rangka mendisiplinkan peserta didik, guru harus mampu menjandi pembimbing, contoh atau teladan, pengawas, dan pengendali seluruh perilaku peserta didik.

d. Akhlak Mulia dan Dapat Menjadi Teladan

Indikator dari kepribadian akhlak mulia dan dapat menjadi teladan yaitu bertindak sesuai norma agama, iman dan takwa, jujur, ikhlas dan memiliki perilaku yang pantas untuk diteladani peserta didik. Guru yang baik harus memiliki akhlak yang mulia dan bisa menjadi teladan bagi peserta didik. Guru haru memiliki akahlak mulia, karena ia adalah penasehat bagi peserta didik, bahkan bagi orang tua, meskipun mereka tidak memiliki latihan khusus sebagai penasehat. Kompetensi kepribadian yang dilandasi dengan akhlak mulia tentunya tidak tumbuh dengan sendirinya, tetapi memerlukan ijtihad yang mujahadah, yakni usaha sungguh-sungguh, kerja keras, tanpa lelah, dengan niat ibadah. Dalam hal ini, setiap guru harus merapatkan kembali barisannya, meluruskan niatnya, bahwa menjadi seorang guru bukan hanya semata-mata untuk kepentingan duniawi, memperbaiki ikhtiar terutama berkaitan dengan kompetensi pribadinya, dengan tetap bertawakkal kepada Allah swt. ${ }^{17}$

Guru merupakan teladan bagi para peserta didik dan semua orang yang menganggap dia sebagai guru. Sebagai teladan, apa saja yang dilakukan guru akan mendapatkan sorotan dari peserta didik serta orang disekitar lingkungannya yang menganggap atau mengikutinya sebagai seorang guru. Disadari atau tidak, kesadaran dari diri seseorang akan berpengaruh pada lingkungan sekitarnya, keteladanan yang diberikan akan memberikan pencitraan yang cukup besar kepada masyarakat dilingkungan tempatnya tinggal. ${ }^{18}$ Menjadi teladan merupakan bagian integral dari seorang guru sehingga menjadi seorang guru berarti menerima tanggung jawab untuk menjadi teladan.

Menjadi teladan merupakan sifat dasar kegiatan pembelajaran, dan ketika seorang guru tidak mau menerima dan menggunakannya secara konstruktif maka telah mengurangi keefektifan pembelajaran.

e. Kepribadian yang Berwibawah

Indikator dari kepribadian yang berwibawah yaitu memiliki perilaku yang berpengaruh positif terhadap peserta didik dan memiliki perilaku yang disegani. ${ }^{19}$ Kewibawaan di sini berarti hak memerintah dan kekuasaan untuk dipatuhi dan ditaati. Ada juga yang mengartikan bahwa kewibawaan adalah sikap dan penampilan yang dapat menimbulkanm rasa segan dan rasa hormat. Sehingga

${ }^{17}$ E. Mulyasa, Standar Kompetensi dan Sertifikasi, h. 124-131.

${ }^{18}$ Chaerul Roochman dan Heri Gunawan, Pengembangan Kompetensi Keperibadian Guru; Menjadi Guru yang Dicintai dan Diteladani oleh Siswa, h. 49.

${ }^{19}$ E. Mulyasa, Standar Kompetensi dan Sertifikasi, h. 127. 
dengan kepribadian guru yang berwibawah, anak didik merasa memperolah pengayoman dan perlindungan.

\section{Motivasi Belajar}

Menurut Kamus Besar Bahasa Indonesia motivasi merupakan dorongan yang timbul pada diri seseorang secara sadar atau tidak sadar untuk melakukan sesuatu tindakan dengan tujuan tertentu. ${ }^{20}$

Istilah motivasi banyak dipakai dalam berbagai bidang dan situasi, tetapi dalam uraian ini akan lebih diarahkan pada bidang pendidikan khususnya dalam bidang pembelajaran. Motivasi dalam Kamus Besar Bahasa Indonesia berpangkal dari kata "motif" atau dalam bahasa Inggrisnya "motive", berasal dari kata "motion", yang berarti gerak atau sesuatu yang bergerak. Jadi istilah motif pun erat hubungannya dengan gerak yaitu dalam artian ini gerak yang akan dilakukan oleh manusia atau disebut juga perbuatan atau tingkah laku. Motif dalam psikologi adalah rangsangan, dorongan, atau pembangkit tenaga bagi terjadinya tingkah laku. $^{21}$

Menurut Hamzah B. Uno, menyatakan bahwa motivasi berasal dari kata motif yang dapat diartikan sebagai kekuatan yang terdapat dalam diri individu, yang menyebabkan individu tersebut bertindak dan berbuat. Motif tidak dapat diamati secara langsung tetapi dapat diinterpretasikan dalam tingkah lakunya berupa rangsangan, dorongan, atau pembangkit tenaga munculnya suatu tingkah laku. ${ }^{22}$

Menurut Santrock, motivasi adalah proses yang memberi semangat, arah, dan kegigihan perilaku. Artinya, perilaku yang memiliki motivasi adalah perilaku yang penuh energi, terarah, dan bertahan lama. Dalam kegiatan belajar, maka motivasi dapat dikatakan sebagai keseluruhan daya penggerak di dalam diri peserta didik yang menimbulkan kegiatan belajar, yang menjamin kelangsungan dari kegiatan belajar dan memberikan arah pada kegiatan belajar, sehingga tujuan yang dikehendaki oleh subjek belajar itu dapat tercapai. ${ }^{23}$

Berdasarkan beberapa penjelasan terkait motivasi belajar sebelumnya, maka penulis dapat mengambil kesimpulan bahwa motivasi belajar adalah daya penggerak yang mendorong serta mengarahkan tingkah laku peserta didik dalam

\footnotetext{
${ }^{20}$ Pusat Bahasa Depertemen Pendidikan Nasional, Kamus Besar Bahasa Indonesia (Cet. I; Jakarta: Balai Pustaka, 2001), h. 782.

${ }^{21}$ Sudirman Sommeng, Psikologi Umum dan Perkembangan (Makassar: Alauddin University Press, 2012), h. 106.

${ }^{22}$ Hamzah B. Uno, Teori Motivasi dan Pengukurannya Analisis di Bidang Pendidikan (Cet. X; Jakarta: Bumi Aksara, 2013), h. 3.

${ }^{23}$ John W. Santrock, Educational Psycology, diterjemahkan oleh Tri Wibowo BS, Psikologi Pendidikan (Jakarta: Kencana, 2004), h. 135.
} 
bentuk kegiatan belajar untuk menambah pengetahuan, keterampilan, serta pengalaman. Sehingga peserta didik bersungguh-sungguh dalam belajar agar meraih prestasi yang dicita-citakannya.

Motivasi belajar dapat timbul karena faktor intrinsik, berupa hasrat, keinginan berhasil dan dorongan kebutuhan belajar, serta harapan akan cita-cita. Sedangkan faktor ekstrinsiknya adalah adanya penghargaan, lingkungan belajar yang kondusif, dan kegiatan belajar yang menarik. Tetapi harus diingat, kedua faktor tersebut disebabkan oleh rangsangan tertentu, sehingga seorang berkeinginan untuk melakukan aktivitas belajar yang lebih giat dan semangat.

Hakikat motivasi belajar merupakan dorongan internal dan eksternal pada peserta didik yang sedang belajar untuk mengadakan perubahan tingkah laku, pada umumnya dengan beberapa indikator atau unsur yang mendukung. Hal tersebut mempunyai peranan besar dalam keberhasilan seseorang dalam belajar. Menurut Hamzah B. Uno indikator motivasi belajar dapat diklasifikasikan seperti: (a) Adanya hasrat dan keinginan berhasil; (b) Adanya dorongan dan kebutuhan dalam belajar; (c) Adanya harapan dan cita-cita masa depan; (d) Adanya penghargaan dalam belajar; (e) Adanya kegiatan yang menarik dalam belajar; (f) Adanya lingkungan belajar yang kondusif. ${ }^{24}$

Indikator-indikator tersebut merupakan hal yang dapat memicu timbulnya motivasi peserta didik untuk belajar, maka dari itu guru sebagai pribadi yang profesional diharapkan mampu untuk memotivasi peserta didik dalam proses pembelajaran dengan keteladan serta keprofesionalan yang ia miliki.

Dalam upaya meningkatkan motivasi belajar peserta didik, seorang guru tentunya harus mengerti bagaimana pola dari motivasi tersebuat, dalam mengingkatkan motivasi tentu beda pola yang dikembangkan oleh guru dalam mendorong terciptanya motivasi belajar peserta didik. Ada empat pola motivasi yang sangat penting untuk diperhatikan oleh seorang guru, yakni prestasi, afiliasi, kompetensi dan kekuasaan.

Dengan demikian seorang pendidik (guru) harusnya memiliki kompetensi yang memadai sehingga bisa memberikan motivasi belajar kepada peserta didik. Adapun kompetensi yang mesti ditingkatkan yakni kompetensi kepribadian dan kompetensi profesional, seorang guru menjadi tauladan yang patut ditiru dan memiliki keluasan pengetahuan yang mampu mendorong keinginan belajar peserta didik.

\section{METODOLOGI PENELITIAN}

\footnotetext{
${ }^{24}$ Hamzah B. Uno, Teori Motivasi dan Pengukurannya Analisis di Bidang Pendidikan, h. 23.
} 
Penelitian ini menggunakan penelitian penjelasan (explanatory research) yatu menjelaskan variabel dependen dan indepensen melalui pengujian hipotesis. Populasi dari penelitian ini adalah seluruh jumlah guru non PNS dan peserta didik, pengambilan sampel untuk guru digunakan sampel jenuh yakni 18 orang dari keseluruhan populasi. Sementara pengambilan sampel untuk peserta didik digunakan dengan rumus:

$$
\begin{aligned}
& \mathrm{n}=\frac{\mathrm{N}}{1+\mathrm{Ne}^{2}} \\
& \mathrm{n}=\frac{515}{1+515(0,1)^{2}}=84
\end{aligned}
$$

Jadi jumlah sampel minimun pada penelitian ini adalah 84 orang peserta didik. teknik yang digunakan untuk memilih sampel adalah stratifed random sampling yaitu memilih sampel secara acak berdasarkan kelompok tertentu, seperti ditunjukkan pada tabel 1.

Tabel 1 Jumlah Peserta Didik MTsN 2 Bone

\begin{tabular}{|c|c|c|c|}
\hline \multirow{2}{*}{ No } & Nama Kelas & \multicolumn{2}{|c|}{ Peserta didk } \\
\cline { 3 - 4 } & & Populasi & Sampel \\
\hline 2 & Kelas VII & 166 & 27 \\
\hline 3 & Kelas VIII & 186 & 30 \\
\hline 4 & Kelas IX & 163 & 27 \\
\hline \multicolumn{2}{|c|}{ Jumlah Peserta Didik } & $\mathbf{5 1 5}$ & $\mathbf{8 4}$ \\
\hline
\end{tabular}

Teknik analisis data yang digunakan adalah data kuantitatif, kemudian dianalisis dengan menggunakan dasar-dasar teoritis dan landasan teori yang sudah ada. Analisis data digunakan analisis regresi linear sederhana dan analisis regresi linear ganda dengan bantuan SPSS 25.

\section{HASIL PENELITIAN DAN PEMBAHASAN}

\section{A. Hasil Penelitian}

1. Kompetensi Kepribadian Guru MTsN 2 Bone

Data hasil penelitian tentang kompetensi kepribadian guru MTsN 2 Bone diperoleh berdasarka 18 responden yang ditabulasi dan diskor, hasil rekapitulasi skor setiap responden mengenai kompetensi kepribadian guru adalah sebagai berikut: 
$\begin{array}{llllllll}80 & 77 & 80 & 79 & 80 & 76 & 72 & 75\end{array}$

Berikut adalah tabel hasil analisis deskriptif data kompetensi kepribadian guru MTsN 2 Bone dengan menggunakan bantuan SPSS 25 sebagai berikut:

Tabel 3 Analisis Descriptive Statistics Kompetensi Kepribadian Guru MTsN 2 Bone

\begin{tabular}{|c|c|}
\hline Statistik & Skor Statistik \\
\hline Sampel & 18 \\
\hline Skor terendah & 69 \\
\hline Skor tertinggi & 80 \\
\hline Rata-rata & 76.01 \\
\hline Standar deviasi & 3.95 \\
\hline
\end{tabular}

Sumber: hasil analisis descriptive (Lampiran 7)

Dari tabel descriptive statistik di atas menjelaskan bahwa kompetensi kepribadian guru MTsN 2 Bone yang didapatkan melalui instrumen menunjukkan bahwa skor tertinggi 80 dan skor terendah adalah 69. Skor rata-rata diperoleh adalah 76,01 dengan standar deviasinya 3,95. Data terkait kompetensi kepribadian guru MTsN 2 Bone, dikategorisasikan dalam bentuk tabel yang digolongkan ke dalam 3 kategori, dengan menggunakan rumus Syaifuddin Azwar sebagai berikut: ${ }^{25}$

Tabel 4 Kategorisasi Kompetensi Kepribadian Guru MTsN 2 Bone

\begin{tabular}{|c|c|c|c|c|}
\hline Batas Kategorisasi & Interval & Frekuensi & Kategori & Persentase \\
\hline$X \geq(\mu+1.0 \circ)$ & $X \geq 79$ & 7 & Tinggi & $39 \%$ \\
\hline$(\mu-1.0 \circ) \leq X<(\mu+1.0 \%)$ & $72 \leq X<79$ & 9 & Sedang & $50 \%$ \\
\hline$X<(\mu+1.0 \%)$ & $X<72$ & 2 & Rendah & $11 \%$ \\
\hline \multicolumn{2}{|r|}{ Jumlah } & $\mathbf{1 8}$ & & $\mathbf{1 0 0 \%}$ \\
\hline
\end{tabular}

Keterangan:

$$
\begin{aligned}
& \mu=\text { Mean } \\
& \alpha=\text { Standar deviasi }
\end{aligned}
$$

${ }^{25}$ Saifuddin Azwar, Penyusunan Skala Psikoligi (Cet. IV; Yogyakarta: Pusat Pelajar, 2013), h. 149. 
Berdasarkan tabel kategori di atas yang melibatkan guru sebanyak 18 sampel, dapat diketahui frekuensi skor dengan kategori tinggi sebanyak 7 guru atau sekitar 39\%, 9 atau 50\% guru berada pada kategori sedang, dan 2 guru atau $11 \%$ berada pada kategori rendah. Hal tersebut mengambarkan bahwa, kompetensi kepribadian guru MTsN 2 Bone berada pada kategori sedang.

a. Motivasi Belajar Peserta Didik MTsN 2 Bone

Deskripsi hasil penelitian ini dimaksudkan untuk menjawab rumusan masalah serta hipotesis dalam memenuhi tujuan dari penelitian ini yang sudah dijelaskan dalam bab I. Data hasil penelitian tentang motivasi belajar peserta didik MTsN 2 Bone diperoleh berdasarka 84 responden yang ditabulasi dan diskor (lampiran 2), hasil rekapitulasi skor setiap responden mengenai motivasi belajar peserta didik adalah sebagai berkut:

$\begin{array}{llllllllll}79 & 86 & 81 & 78 & 88 & 87 & 83 & 84 & 82 & 86 \\ 85 & 87 & 90 & 86 & 90 & 85 & 84 & 84 & 88 & 89 \\ 80 & 79 & 65 & 68 & 78 & 73 & 79 & 74 & 73 & 85 \\ 77 & 87 & 79 & 77 & 76 & 75 & 81 & 68 & 75 & 74 \\ 75 & 76 & 76 & 69 & 80 & 75 & 75 & 83 & 71 & 81 \\ 74 & 76 & 79 & 76 & 78 & 80 & 79 & 79 & 87 & 76 \\ 71 & 86 & 83 & 87 & 78 & 84 & 77 & 71 & 74 & 71 \\ 82 & 73 & 79 & 75 & 68 & 77 & 82 & 67 & 67 & 73 \\ 69 & 82 & 80 & 72 & & & & & & \end{array}$

Berikut adalah tabel hasil analisis deskriptif data motivasi belajar peserta didik MTsN 2 Bone dengan menggunakan bantuan SPSS 25 sebagai berikut:

Tabel 5 Analisis Descriptive Statistics Motivasi Belajar Peserta Didik MTsN 2 Bone

\begin{tabular}{|c|c|}
\hline Statistik & Skor Statistik \\
\hline Sampel & 84 \\
\hline Skor terendah & 65 \\
\hline Skor tertinggi & 90 \\
\hline Rata-rata & 78.55 \\
\hline Standar deviasi & 6.08 \\
\hline
\end{tabular}

Sumber: hasil analisis descriptive (Lampiran 7)

Dari tabel descriptive statistik di atas menjelaskan bahwa motivasi belajar peserta didik MTsN 2 Bone yang didapatkan melalui instrumen menunjukkan 
bahwa skor tertinggi 90 dan skor terendah adalah 65. Skor rata-rata diperoleh adalah 78.55 dengan standar deviasinya 6.08.

Data terkait motivasi belajar peserta didik MTsN 2 Bone, dikategorisasikan dalam bentuk tabel yang digolongkan ke dalam 3 kategori, dengan menggunakan rumus Syaifuddin Azwar sebagai berikut:

Tabel 6 Kategorisasi Motivasi Belajar Peserta Didik MTsN 2 Bone

\begin{tabular}{|c|c|c|c|c|}
\hline Batas Kategorisasi & Interval & Frekuensi & Kategori & Persentase \\
\hline$X \geq(\mu+1.0 \circ)$ & $X \geq 84$ & 21 & Tinggi & $25 \%$ \\
\hline$(\mu-1.0 \circ) \leq X<(\mu+1.0 \%)$ & $72 \leq X<84$ & 51 & Sedang & $61 \%$ \\
\hline$X<(\mu+1.0 \%)$ & $X<72$ & 12 & Rendah & $14 \%$ \\
\hline \multicolumn{2}{|r|}{ Jumlah } & $\mathbf{8 4}$ & & $\mathbf{1 0 0 \%}$ \\
\hline
\end{tabular}

Keterangan:

$$
\begin{aligned}
& \mu=\text { Mean } \\
& \alpha=\text { Standar deviasi }
\end{aligned}
$$

Berdasarkan tabel kategori di atas yang melibatkan peserta didik sebanyak 84 sampel, dapat diketahui frekuensi skor dengan kategori tinggi sebanyak 21 peserta didik atau sekitar 25\%, 51 atau $61 \%$ peserta didik berada pada kategori sedang, dan 12 atau $14 \%$ peserta didik berada pada kategori rendah. Hal tersebut mengambarkan bahwa, motivasi belajar peserta didik MTsN 2 Bone berada pada kategori tinggi.

b. Pengaruh Kompetensi Kepribadian Guru terhadap Motivasi Belajar

Untuk mengukur pengaruh kompetensi kepribadian guru terhadap motivasi belajar peserta didik MTsN 2 Bone digunakan statistik inferensial untuk menguji hipotesis. Untuk mengetahui seberapa besar pengaruh kompetensi kepribadian guru terhadap motivasi belajar peserta didik dapat diketahui dengan menggunakan bantuan program SPSS 25 dengan hasil sebagai berikut:

\section{Tabel 7 Hasil Analisis Korelasi X1 terhadap Y Coefficients $^{a}$}

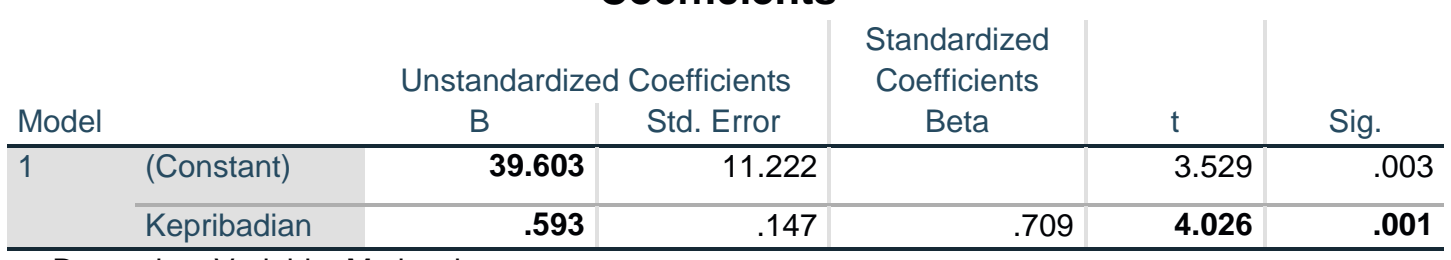

a. Dependent Variable: Motivasi

Model Summary ${ }^{\mathrm{b}}$ 


\begin{tabular}{|c|c|c|c|c|}
\hline Model & $\mathrm{R}$ & R Square & $\begin{array}{l}\text { Adjusted R } \\
\text { Square }\end{array}$ & $\begin{array}{c}\text { Std. Error of the } \\
\text { Estimate }\end{array}$ \\
\hline 1 & $.709^{a}$ & .503 & .472 & 2.401 \\
\hline
\end{tabular}

1) Persamaan Regresi Sederhana $X 1$ terhadap $Y$

Dari tabel coefficients diperoleh informasi niali $\mathrm{a}=39.603$ dan $\mathrm{b}=0.593$, sehingga persamaan regresi sederhana X1 terhadap $\mathrm{Y}$ adalah $\dot{\mathrm{Y}}=39.603+$ $0.593 \mathrm{X}_{1}$.

2) Uji Hipotesis

Uji hipotesis dilakukan untuk melihat adanya pengaruh variabel independen terhadap variabel dependen dengan membandingkan nilai t hitung dengan nilai t tabel. Dasar dalam menentukan t tabel dengan rumus $=(\alpha / 2 ; n-k-1)$ $=(0.05 / 2 ; 18-2-1)=(0.025 ; 15)=2.131$.

Dari tabel coefficients diperoleh nilai t hitung $=4.026>2.131 \mathrm{t}$ tabel, sehingga $\mathrm{H}_{0}$ ditolak dan $\mathrm{H}_{1}$ diterima. Dengan demikian, terdapat pengaruh kompetensi kepribadian guru terhadap motivasi belajar peserta didik MTsN 2 Bone.

3) Koefisien Korelasi

Nilai koefisien korelasi X1 terhadap $\mathrm{Y}$ berdasarkan tabel model summary adalah nilai $\mathrm{R}=0.709$. koefisien determinasi antara $\mathrm{X} 1$ dan $\mathrm{Y}$ adalah $0.709^{2} \mathrm{x}$ $100 \%=50.26 \%$ dan dibulatkan menjadi 50.3\% . Dengan demikian besaran pengaruh kompetensi kepribadian guru terhadap motivasi belajar peserta didik MTsN 2 Bone sebesar $50.3 \%$ dan $49.7 \%$ dipengaruhi oleh varian lain.

\section{Pembahasan}

a. Kompetensi Kepribadian Guru MTsN 2 Bone

Berdasarkan pernyataan Jamil Suprihatiningrum yang mengatakan bahwa kompetensi kepribadian guru adalah kemampuan personal yang mencerminkan kepribadian yang mantap dan stabil, dewasa, arif, berwibawah, menjadi teladan bagi siswa, dan berakhlak mulia, hal ini menjadi tolak ukur dalam menilai kompetensi kepribadian guru di MTsN 2 Bone.

Untuk membahas kompetensi kepribadian guru MTsN 2 Bone kita harus merujuk pada empat kategori yakni sangat sering (setiap saat melakukan), sering (lebih banyak melakukan), kadang-kadang (lebih jarang melakukan), dan tidak pernah (tidak pernah melakukan). Untuk melihat kompetensi kepribadian guru MTsN 2 Bone akan dituangkan ke dalam bentuk tabel setiap indikator berikut ini:

Gambaran kompetensi kepribadian guru MTsN 2 Bone dalam hal ini indikator kepribadian yang mantap dan stabil dapat dilihat pada tabel berikut: 
Tabel 8 Distribusi Frekuensi Data Kompetensi Kepribadian Guru MTsN 2 Bone untuk Indikator Mantap dan Stabil

\begin{tabular}{|c|c|c|c|c|c|c|c|c|c|c|c|}
\hline Indikator & $\begin{array}{c}\text { No } \\
\text { Soal }\end{array}$ & \multicolumn{2}{|c|}{$\begin{array}{c}\text { Sangat } \\
\text { Sering }\end{array}$} & \multicolumn{2}{|c|}{ Sering } & \multicolumn{2}{|c|}{$\begin{array}{c}\text { Kadang- } \\
\text { kadang }\end{array}$} & \multicolumn{2}{|c|}{$\begin{array}{c}\text { Tidak } \\
\text { Pernah }\end{array}$} & \multicolumn{2}{|c|}{ Jumlah } \\
\cline { 2 - 13 } & & $\mathrm{F}$ & $\%$ & $\mathrm{~F}$ & $\%$ & $\mathrm{~F}$ & $\%$ & $\mathrm{~F}$ & $\%$ & $\mathrm{~F}$ & $\%$ \\
\hline $\begin{array}{c}\text { Kepribadian } \\
\text { mantap dan } \\
\text { stabil }\end{array}$ & 1 & 14 & 78 & 4 & 22 & 0 & 0 & 0 & 0 & 18 & 100 \\
\cline { 2 - 14 } & 2 & 12 & 67 & 5 & 27 & 1 & 6 & 0 & 0 & 18 & 100 \\
\cline { 2 - 14 } & 10 & 56 & 6 & 33 & 2 & 11 & 0 & 0 & 18 & 100 \\
\hline \multicolumn{2}{|c|}{ Rata-rata } & 12 & 67 & 5 & 27 & 1 & 6 & 0 & 0 & 18 & 100 \\
\hline
\end{tabular}

Sumber : Olah data hasil penelitian

Berdasarkan tabel di atas, menunjukkan bahwa kompetensi kepribadian guru terkait indikator kepribadian yang mantap dan stabil memiliki rata-rata jawaban "sangat sering" sebanyak 12 orang guru atau sebesar $67 \%$ dari 18 orang guru, jawaban "sering" sebanyak 5 orang guru atau sebesar $27 \%$ dari 18 orang guru, jawaban "kadang-kadang" sebanyak 1 orang guru atau sebesar 6\% dari 18 orang guru, serta tidak ada guru yang menjawab "tidak pernah". Kesimpulanya untuk indikator mantap dan stabil memiliki rata-rata jawaban paling banyak adalah "sangat sering".

Gambaran kompetensi kepribadian guru MTsN 2 Bone dalam hal ini indikator kepribadian dewasa dapat dilihat pada tabel berikut:

Tabel 9 Distribusi Frekuensi Data Kompetensi Kepribadian Guru MTsN 2

Bone untuk Indikator Dewasa

\begin{tabular}{|c|c|c|c|c|c|c|c|c|c|c|c|}
\hline Indikator & $\begin{array}{c}\text { No } \\
\text { Soal }\end{array}$ & \multicolumn{2}{|c|}{$\begin{array}{c}\text { Sangat } \\
\text { Sering }\end{array}$} & \multicolumn{2}{|c|}{ Sering } & \multicolumn{2}{|c|}{$\begin{array}{c}\text { Kadang- } \\
\text { kadang }\end{array}$} & \multicolumn{2}{|c|}{$\begin{array}{c}\text { Tidak } \\
\text { Pernah }\end{array}$} & \multicolumn{2}{|c|}{ Jumlah } \\
\cline { 2 - 13 } & & $\mathrm{F}$ & $\%$ & $\mathrm{~F}$ & $\%$ & $\mathrm{~F}$ & $\%$ & $\mathrm{~F}$ & $\%$ & $\mathrm{~F}$ & $\%$ \\
\hline $\begin{array}{c}\text { Kepribadian } \\
\text { Dewasa }\end{array}$ & 4 & 13 & 72 & 3 & 17 & 2 & 11 & 0 & 0 & 18 & 100 \\
\cline { 2 - 14 } & 5 & 16 & 89 & 2 & 11 & 0 & 0 & 0 & 0 & 18 & 100 \\
\cline { 2 - 14 } & 6 & 15 & 83 & 3 & 17 & 0 & 0 & 0 & 0 & 18 & 100 \\
\hline \multicolumn{2}{|c|}{ Rata-rata } & 14 & 81 & 3 & 15 & 1 & 4 & 0 & 0 & 18 & 100 \\
\hline
\end{tabular}

Sumber : Olah data hasil penelitian

Berdasarkan tabel di atas, menunjukkan bahwa kompetensi kepribadian guru terkait indikator kepribadian yang dewasa memiliki rata-rata jawaban 
"sangat sering" sebanyak 14 orang guru atau sebesar $81 \%$ dari 18 orang guru, jawaban "sering" sebanyak 3 orang guru atau sebesar $15 \%$ dari 18 orang guru, jawaban "kadang-kadang" sebanyak 1 orang guru atau sebesar $4 \%$ dari 18 orang guru, serta tidak ada guru yang menjawab "tidak pernah". Kesimpulanya untuk indikator dewasa memiliki rata-rata jawaban paling banyak adalah "sangat sering".

Gambaran kompetensi kepribadian guru MTsN 2 Bone dalam hal ini indikator kepribadian yang arif dapat dilihat pada tabel berikut:

Tabel 10 Distribusi Frekuensi Data Kompetensi Kepribadian Guru MTsN 2 Bone untuk Indikator Arif

\begin{tabular}{|c|c|c|c|c|c|c|c|c|c|c|c|}
\hline Indikator & $\begin{array}{c}\text { No } \\
\text { Soal }\end{array}$ & \multicolumn{2}{|c|}{$\begin{array}{c}\text { Sangat } \\
\text { Sering }\end{array}$} & \multicolumn{2}{|c|}{ Sering } & \multicolumn{2}{|c|}{$\begin{array}{c}\text { Kadang- } \\
\text { kadang }\end{array}$} & \multicolumn{2}{|c|}{$\begin{array}{c}\text { Tidak } \\
\text { Pernah }\end{array}$} & \multicolumn{2}{|c|}{ Jumlah } \\
\cline { 2 - 12 } & & $\mathrm{F}$ & $\%$ & $\mathrm{~F}$ & $\%$ & $\mathrm{~F}$ & $\%$ & $\mathrm{~F}$ & $\%$ & $\mathrm{~F}$ & $\%$ \\
\hline $\begin{array}{c}\text { Kepribadian } \\
\text { yang arif }\end{array}$ & 7 & 18 & 100 & 0 & 0 & 0 & 0 & 0 & 0 & 18 & 100 \\
\cline { 2 - 13 } & 8 & 18 & 100 & 0 & 0 & 0 & 0 & 0 & 0 & 18 & 100 \\
\cline { 2 - 13 } & 9 & 13 & 72 & 5 & 28 & 0 & 0 & 0 & 0 & 18 & 100 \\
\hline Rata-rata & 16 & 91 & 2 & 9 & 0 & 0 & 0 & 0 & 8 & 100 \\
\hline
\end{tabular}

Sumber : Olah data hasil penelitian

Berdasarkan tabel di atas, menunjukkan bahwa kompetensi kepribadian guru terkait indikator kepribadian yang arif memiliki rata-rata jawaban "sangat sering" sebanyak 16 orang guru atau sebesar $91 \%$ dari 18 orang guru, jawaban "sering" sebanyak 2 orang guru atau sebesar 9\% dari 18 orang guru, serta tidak ada guru yang menjawab "kadang-kadang" dan "tidak pernah". Kesimpulanya untuk indikator kepribadian yang arif memiliki rata-rata jawaban paling banyak adalah "sangat sering".

Gambaran kompetensi kepribadian guru MTsN 2 Bone dalam hal ini indikator berwibawah dapat dilihat pada tabel berikut: 
Tabel 11 Distribusi Frekuensi Data Kompetensi Kepribadian Guru MTsN 2 Bone untuk Indikator Berwibawah

\begin{tabular}{|c|c|c|c|c|c|c|c|c|c|c|c|}
\hline \multirow[t]{2}{*}{ Indikator } & \multirow[t]{2}{*}{$\begin{array}{l}\text { No } \\
\text { Soal }\end{array}$} & \multicolumn{2}{|c|}{$\begin{array}{l}\text { Sangat } \\
\text { Sering }\end{array}$} & \multicolumn{2}{|c|}{ Sering } & \multicolumn{2}{|c|}{$\begin{array}{l}\text { Kadang- } \\
\text { kadang }\end{array}$} & \multicolumn{2}{|c|}{$\begin{array}{c}\text { Tidak } \\
\text { Pernah }\end{array}$} & \multicolumn{2}{|c|}{ Jumlah } \\
\hline & & $\mathrm{F}$ & $\%$ & $\mathrm{~F}$ & $\%$ & $\mathrm{~F}$ & $\%$ & $\mathrm{~F}$ & $\%$ & $\mathrm{~F}$ & $\%$ \\
\hline \multirow{3}{*}{$\begin{array}{l}\text { Kepribadian } \\
\text { berwibawah }\end{array}$} & 10 & 18 & 100 & 0 & 0 & 0 & 0 & 0 & 0 & 18 & 100 \\
\hline & 11 & 15 & 83 & 3 & 17 & 0 & 0 & 0 & 0 & 18 & 100 \\
\hline & 12 & 17 & 94 & 1 & 6 & 0 & 0 & 0 & 0 & 18 & 100 \\
\hline \multicolumn{2}{|c|}{ Rata-rata } & 16 & 92 & 2 & 8 & 0 & 0 & 0 & 0 & 8 & 100 \\
\hline
\end{tabular}

Sumber : Olah data hasil penelitian

Berdasarkan tabel di atas, menunjukkan bahwa kompetensi kepribadian guru terkait indikator kepribadian yang berwibawah memiliki rata-rata jawaban "sangat sering" sebanyak 16 orang guru atau sebesar $92 \%$ dari 18 orang guru, jawaban "sering" sebanyak 2 orang guru atau sebesar $2 \%$ dari 18 orang guru, serta tidak ada guru yang menjawab "kadang-kadang" dan "tidak pernah". Kesimpulanya untuk indikator berwibawah memiliki rata-rata jawaban paling banyak adalah "sangat sering".

Gambaran kompetensi kepribadian guru MTsN 2 Bone dalam hal ini indikator kepribadian menjadi teladan dapat dilihat pada tabel berikut:

Tabel 12 Distribusi Frekuensi Data Kompetensi Kepribadian Guru MTsN 2 Bone untuk Indikator Menjadi Teladan

\begin{tabular}{|c|c|c|c|c|c|c|c|c|c|c|c|}
\hline \multirow[t]{2}{*}{ Indikator } & \multirow[t]{2}{*}{$\begin{array}{l}\text { No } \\
\text { Soal }\end{array}$} & \multicolumn{2}{|c|}{$\begin{array}{l}\text { Sangat } \\
\text { Sering }\end{array}$} & \multicolumn{2}{|c|}{ Sering } & \multicolumn{2}{|c|}{$\begin{array}{l}\text { Kadang- } \\
\text { kadang }\end{array}$} & \multicolumn{2}{|c|}{$\begin{array}{l}\text { Tidak } \\
\text { Pernah }\end{array}$} & \multicolumn{2}{|c|}{ Jumlah } \\
\hline & & $\mathrm{F}$ & $\%$ & $\mathrm{~F}$ & $\%$ & $\mathrm{~F}$ & $\%$ & $\mathrm{~F}$ & $\%$ & $\mathrm{~F}$ & $\%$ \\
\hline \multirow{4}{*}{$\begin{array}{l}\text { Menjadi } \\
\text { teladan }\end{array}$} & 13 & 17 & 94 & 1 & 6 & 0 & 0 & 0 & 0 & 18 & 100 \\
\hline & 14 & 14 & 78 & 4 & 22 & 0 & 0 & 0 & 0 & 18 & 100 \\
\hline & 15 & 14 & 78 & 4 & 22 & 0 & 0 & 0 & 0 & 18 & 100 \\
\hline & 16 & 15 & 83 & 3 & 17 & 0 & 0 & 0 & 0 & 18 & 100 \\
\hline \multicolumn{2}{|c|}{ Rata-rata } & 15 & 83 & 3 & 17 & 0 & 0 & 0 & 0 & 18 & 100 \\
\hline
\end{tabular}

Sumber : Olah data hasil penelitian

Berdasarkan tabel di atas, menunjukkan bahwa kompetensi kepribadian guru terkait indikator kepribadian menjadi teladan memiliki rata-rata jawaban 
"sangat sering" sebanyak 15 orang guru atau sebesar $83 \%$ dari 18 orang guru, jawaban "sering" sebanyak 3 orang guru atau sebesar 17\% dari 18 orang guru, dan tidak ada yang memilih untuk kategori "kadang-kadang" dan "tidak pernah". Kesimpulanya untuk indikator menjadi teladan memiliki rata-rata jawaban paling banyak adalah "sangat sering".

Gambaran kompetensi kepribadian guru MTsN 2 Bone dalam hal ini indikator kepribadian akhlak mulia dapat dilihat pada tabel berikut:

Tabel 13 Distribusi Frekuensi Data Kompetensi Kepribadian Guru MTsN 2 Bone untuk Indikator Akhlak Mulia

\begin{tabular}{|c|c|c|c|c|c|c|c|c|c|c|c|}
\hline \multirow[t]{2}{*}{ Indikator } & \multirow[t]{2}{*}{$\begin{array}{l}\text { No } \\
\text { Soal }\end{array}$} & \multicolumn{2}{|c|}{$\begin{array}{l}\text { Sangat } \\
\text { Sering }\end{array}$} & \multicolumn{2}{|c|}{ Sering } & \multicolumn{2}{|c|}{$\begin{array}{r}\text { Kadang- } \\
\text { kadang }\end{array}$} & \multicolumn{2}{|c|}{$\begin{array}{c}\text { Tidak } \\
\text { Pernah }\end{array}$} & \multicolumn{2}{|c|}{ Jumlah } \\
\hline & & $\mathrm{F}$ & $\%$ & $\mathrm{~F}$ & $\%$ & $\mathrm{~F}$ & $\%$ & $\mathrm{~F}$ & $\%$ & $\mathrm{~F}$ & $\%$ \\
\hline \multirow{4}{*}{$\begin{array}{c}\text { Akhlak } \\
\text { mulia }\end{array}$} & 17 & 18 & 100 & 0 & 0 & 0 & 0 & 0 & 0 & 18 & 100 \\
\hline & 18 & 12 & 67 & 6 & 33 & 0 & 0 & 0 & 0 & 18 & 100 \\
\hline & 19 & 17 & 94 & 1 & 6 & 0 & 0 & 0 & 0 & 18 & 100 \\
\hline & 20 & 13 & 72 & 3 & 17 & 0 & 0 & 2 & 11 & 18 & 100 \\
\hline \multicolumn{2}{|c|}{ Rata-rata } & 15 & 83 & 2 & 14 & 0 & 0 & 1 & 3 & 18 & 100 \\
\hline
\end{tabular}

Sumber : Olah data hasil penelitian

Berdasarkan tabel di atas, menunjukkan bahwa kompetensi kepribadian guru terkait indikator akhlak mulia memiliki rata-rata jawaban "sangat sering" sebanyak 15 orang guru atau sebesar $83 \%$ dari 18 orang guru, jawaban "sering" sebanyak 2 orang guru atau sebesar $14 \%$ dari 18 orang guru, dan tidak ada yang memilih untuk kategori "kadang-kadang" sementara jawaban "tidak pernah". Sebanyak 1 orang guru atau 3\%. Kesimpulanya untuk indikator akhlak mulia memiliki rata-rata jawaban paling banyak adalah "sangat sering".

Berdasarkan hasil distribusi frekuensi kompetensi kepribadian guru yang di dapat dari jawaban guru non PNS MTsN 2 Bone yang dilihat dari 6 (enam) indikator bahwa sebagian besar jawaban tersebut, menunjukkan guru telah memiliki kompetensi kepribadian yang sangat baik dalam proses pembelajaran.

b. Motivasi Belajar Peserta Didik MTsN 2 Bone

Berdasarkan pada pendapatnya Santrock bahwa motivasi adalah proses yang memberi semangat, arah, dan kegigihan perilaku dengan beberapa indikator seperti adanya hasrat dan keinginan berhasil, adanya dorongan dan kebutuhan dalam belajar, adanya harapan dan cita-cita masa depan, adanya penghargaan dalam belajar, adanya kegiatan yang menarik dalam belajar, dan adanya 
lingkungan belajar yang kondusif. Hal ini menjadi tolak ukur dalam menilai motivasi belajar peserta didik di MTsN 2 Bone.

Gambaran motivasi belajar peserta didik MTsN 2 Bone dalam hal ini indikator adanya hasrat dan keinginan berhasil dapat dilihat pada tabel berikut:

Tabel 14 Distribusi Frekuensi Data Motivasi Belajar Peserta Didik MTsN 2 Bone untuk Indikator Adanya Hasrat dan Keinginan Berhasil

\begin{tabular}{|c|c|c|c|c|c|c|c|c|c|c|c|}
\hline \multirow[t]{2}{*}{ Indikator } & \multirow[t]{2}{*}{$\begin{array}{l}\text { No } \\
\text { Soal }\end{array}$} & \multicolumn{2}{|c|}{$\begin{array}{l}\text { Sangat } \\
\text { Setuju }\end{array}$} & \multicolumn{2}{|c|}{ Setuju } & \multicolumn{2}{|c|}{$\begin{array}{l}\text { Kurang } \\
\text { Setuju }\end{array}$} & \multicolumn{2}{|c|}{$\begin{array}{l}\text { Tidak } \\
\text { Setuju }\end{array}$} & \multicolumn{2}{|c|}{ Jumlah } \\
\hline & & $\mathrm{F}$ & $\%$ & $\mathrm{~F}$ & $\%$ & $\mathrm{~F}$ & $\%$ & F & $\%$ & $\mathrm{~F}$ & $\%$ \\
\hline \multirow{4}{*}{$\begin{array}{l}\text { Adanya } \\
\text { hasrat dan } \\
\text { keinginan } \\
\text { berhasil }\end{array}$} & 1 & 28 & 34 & 49 & 58 & 5 & 6 & 2 & 2 & 84 & 100 \\
\hline & 2 & 32 & 39 & 44 & 52 & 7 & 8 & 1 & 1 & 84 & 100 \\
\hline & 3 & 29 & 34 & 45 & 54 & 10 & 12 & 0 & 0 & 84 & 100 \\
\hline & 4 & 34 & 41 & 43 & 51 & 7 & 8 & 0 & 0 & 84 & 100 \\
\hline \multicolumn{2}{|c|}{ Rata-rata } & 30 & 36 & 44 & 52 & 9 & 11 & 1 & 1 & 84 & 100 \\
\hline
\end{tabular}

Sumber : Olah data hasil penelitian

Berdasarkan tabel di atas, menunjukkan bahwa motivasi belajar peserta didik terkait indikator hasrat dan keinginan berhasil memiliki rata-rata jawaban "sangat setuju" sebanyak 30 orang peserta didik atau sebesar $36 \%$ dari 84 orang peserta didik, jawaban "setuju" sebanyak 44 orang peserta didik atau sebesar 52\% dari 84 orang peserta didik, jawaban "kurang setuju" sebanyak 9 orang peserta didik atau sebesar $11 \%$ dari 84 peserta didik, sementara jawaban "tidak setuju" sebanyak 1 orang peserta. Kesimpulanya untuk indikator hasrat dan keinginan berhasil memiliki rata-rata jawaban paling banyak adalah "setuju".

Gambaran motivasi belajar peserta didik MTsN 2 Bone dalam hal ini indikator adanya dorongan dan kebutuhan dalam belajar dapat dilihat pada tabel berikut: 
Tabel 15 Distribusi Frekuensi Data Motivasi Belajar Peserta Didik MTsN 2 Bone untuk Indikator Adanya Dorongan dan Kebutuhan Dalam Belajar

\begin{tabular}{|l|c|c|c|c|c|c|c|c|c|c|c|}
\hline Indikator & $\begin{array}{c}\text { No } \\
\text { Soal }\end{array}$ & \multicolumn{2}{|c|}{$\begin{array}{c}\text { Sangat } \\
\text { Setuju }\end{array}$} & \multicolumn{2}{|c|}{ Setuju } & \multicolumn{2}{c|}{$\begin{array}{c}\text { Kurang } \\
\text { Setuju }\end{array}$} & \multicolumn{2}{c|}{$\begin{array}{c}\text { Tidak } \\
\text { Setuju }\end{array}$} & \multicolumn{2}{c|}{ Jumlah } \\
\cline { 2 - 13 } & $\mathrm{F}$ & $\%$ & $\mathrm{~F}$ & $\%$ & $\mathrm{~F}$ & $\%$ & $\mathrm{~F}$ & $\%$ & $\mathrm{~F}$ & $\%$ \\
\hline $\begin{array}{l}\text { Adanya } \\
\text { dorongan } \\
\text { dan } \\
\text { kebutuhan } \\
\text { dalam belajar }\end{array}$ & 5 & 47 & 56 & 33 & 39 & 4 & 5 & 0 & 0 & 84 & 100 \\
\cline { 2 - 14 } & 6 & 53 & 63 & 22 & 26 & 9 & 11 & 0 & 0 & 84 & 100 \\
\cline { 2 - 14 } & 8 & 37 & 44 & 43 & 51 & 4 & 5 & 0 & 0 & 84 & 100 \\
\hline \multicolumn{2}{|c|}{ Rata-rata } & 42 & 50 & 36 & 43 & 6 & 7 & 0 & 0 & 84 & 100 \\
\hline
\end{tabular}

Sumber : Olah data hasil penelitian

Berdasarkan tabel di atas, menunjukkan bahwa motivasi belajar peserta didik terkait indikator adanya dorongan dan kebutuhan dalam belajar memiliki rata-rata jawaban "sangat setuju" sebanyak 42 orang peserta didik atau sebesar $50 \%$ dari 84 orang peserta didik, jawaban "setuju" sebanyak 36 orang peserta didik atau sebesar $43 \%$ dari 84 orang peserta didik, jawaban "kurang setuju" sebanyak 6 orang peserta didik atau sebesar $7 \%$ dari 84 peserta didik, sementara tidak ada jawaban "tidak setuju". Kesimpulanya untuk indikator adanya dorongan dan kebutuhan dalam belajar memiliki rata-rata jawaban paling banyak adalah "sangat setuju".

Gambaran motivasi belajar peserta didik MTsN 2 Bone dalam hal ini indikator adanya harapan dan cita-cita masa depan dapat dilihat pada tabel berikut:

Tabel 16 Distribusi Frekuensi Data Motivasi Belajar Peserta Didik MTsN 2 Bone untuk Indikator Adanya Harapan dan Cita-Cita Masa Depan

\begin{tabular}{|c|c|c|c|c|c|c|c|c|c|c|c|}
\hline \multirow[t]{2}{*}{ Indikator } & \multirow[t]{2}{*}{$\begin{array}{l}\text { No } \\
\text { Soal }\end{array}$} & \multicolumn{2}{|c|}{$\begin{array}{l}\text { Sangat } \\
\text { Setuju }\end{array}$} & \multicolumn{2}{|c|}{ Setuju } & \multicolumn{2}{|c|}{$\begin{array}{l}\text { Kurang } \\
\text { Setuju }\end{array}$} & \multicolumn{2}{|c|}{$\begin{array}{l}\text { Tidak } \\
\text { Setuju }\end{array}$} & \multicolumn{2}{|c|}{ Jumlah } \\
\hline & & $\mathrm{F}$ & $\%$ & $\mathrm{~F}$ & $\%$ & $\mathrm{~F}$ & $\%$ & $\mathrm{~F}$ & $\%$ & $\mathrm{~F}$ & $\%$ \\
\hline \multirow{3}{*}{$\begin{array}{l}\text { Adanya } \\
\text { harapan dan } \\
\text { cita-cita } \\
\text { masa depan }\end{array}$} & 9 & 71 & 85 & 11 & 13 & 2 & 2 & 0 & 0 & 84 & 100 \\
\hline & 10 & 66 & 79 & 16 & 19 & 2 & 2 & 0 & 0 & 84 & 100 \\
\hline & 11 & 69 & 82 & 15 & 18 & 0 & 0 & 0 & 0 & 84 & 100 \\
\hline \multicolumn{2}{|c|}{ Rata-rata } & 69 & 82 & 14 & 17 & 1 & 1 & 0 & 0 & 84 & 100 \\
\hline
\end{tabular}


Sumber : Olah data hasil penelitian

Berdasarkan tabel di atas, menunjukkan bahwa motivasi belajar peserta didik terkait indikator adanya harapan dan cita-cita masa depan dalam belajar memiliki rata-rata jawaban "sangat setuju" sebanyak 69 orang peserta didik atau sebesar $82 \%$ dari 84 orang peserta didik, jawaban "setuju" sebanyak 14 orang peserta didik atau sebesar $17 \%$ dari 84 orang peserta didik, jawaban "kurang setuju" sebanyak 1 orang peserta didik atau sebesar $1 \%$ dari 84 peserta didik, sementara tidak ada jawaban "tidak setuju". Kesimpulanya untuk indikator adanya harapan dan cita-cita masa depan memiliki rata-rata jawaban paling banyak adalah "sangat setuju".

Gambaran motivasi belajar peserta didik MTsN 2 Bone dalam hal ini indikator adanya penghargaan dalam belajar dapat dilihat pada tabel berikut:

Tabel 17 Distribusi Frekuensi Data Motivasi Belajar Peserta Didik MTsN 2 Bone untuk Indikator Adanya Penghargaan dalam Belajar

\begin{tabular}{|c|c|c|c|c|c|c|c|c|c|c|c|}
\hline Indikator & $\begin{array}{c}\text { No } \\
\text { Soal }\end{array}$ & \multicolumn{2}{|c|}{$\begin{array}{c}\text { Sangat } \\
\text { Setuju }\end{array}$} & \multicolumn{2}{|c|}{ Setuju } & \multicolumn{2}{c|}{$\begin{array}{c}\text { Kurang } \\
\text { Setuju }\end{array}$} & \multicolumn{2}{c|}{$\begin{array}{c}\text { Tidak } \\
\text { Setuju }\end{array}$} & \multicolumn{2}{|c|}{ Jumlah } \\
\cline { 2 - 13 } & & $\mathrm{F}$ & $\%$ & $\mathrm{~F}$ & $\%$ & $\mathrm{~F}$ & $\%$ & $\mathrm{~F}$ & $\%$ & $\mathrm{~F}$ & $\%$ \\
\hline $\begin{array}{l}\text { Adanya } \\
\text { penghargaan } \\
\text { dalam belajar }\end{array}$ & 12 & 61 & 74 & 21 & 25 & 1 & 1 & 0 & 0 & 84 & 100 \\
\cline { 2 - 14 } & 14 & 24 & 29 & 40 & 47 & 19 & 23 & 1 & 1 & 84 & 100 \\
\cline { 2 - 13 } & 15 & 38 & 46 & 40 & 47 & 5 & 6 & 1 & 1 & 84 & 100 \\
\hline \multicolumn{2}{|c|}{ Rata-rata } & 38 & 46 & 37 & 44 & 8 & 9 & 1 & 1 & 84 & 100 \\
\hline
\end{tabular}

Sumber : Olah data hasil penelitian

Berdasarkan tabel di atas, menunjukkan bahwa motivasi belajar peserta didik terkait indikator adanya penghargaan dalam belajar memiliki rata-rata jawaban "sangat setuju" sebanyak 38 orang peserta didik atau sebesar 46\% dari 84 orang peserta didik, jawaban "setuju" sebanyak 37 orang peserta didik atau sebesar $44 \%$ dari 84 orang peserta didik, jawaban "kurang setuju" sebanyak 8 orang peserta didik atau sebesar $9 \%$ dari 84 peserta didik, sementara jawaban "tidak setuju" sebanyak 1 orang atau sebesar $1 \%$ dari 84 peserta didik. Kesimpulanya untuk indikator adanya penghargaan dalam belajar memiliki ratarata jawaban paling banyak adalah "sangat setuju".

Gambaran motivasi belajar peserta didik MTsN 2 Bone dalam hal ini indikator adanya kegiatan yang menarik dalam belajar dapat dilihat pada tabel berikut: 
Tabel 18 Distribusi Frekuensi Data Motivasi Belajar Peserta Didik MTsN 2 Bone untuk Indikator Adanya Kegiatan Yang Menarik dalam Belajar

\begin{tabular}{|c|c|c|c|c|c|c|c|c|c|c|c|}
\hline \multirow[t]{2}{*}{ Indikator } & \multirow[t]{2}{*}{$\begin{array}{l}\text { No } \\
\text { Soal }\end{array}$} & \multicolumn{2}{|c|}{$\begin{array}{l}\text { Sangat } \\
\text { Setuju }\end{array}$} & \multicolumn{2}{|c|}{ Setuju } & \multicolumn{2}{|c|}{$\begin{array}{c}\text { Kurang } \\
\text { Setuju }\end{array}$} & \multicolumn{2}{|c|}{$\begin{array}{l}\text { Tidak } \\
\text { Setuju }\end{array}$} & \multicolumn{2}{|c|}{ Jumlah } \\
\hline & & $\mathrm{F}$ & $\%$ & $\mathrm{~F}$ & $\%$ & $\mathrm{~F}$ & $\%$ & $\mathrm{~F}$ & $\%$ & $\mathrm{~F}$ & $\%$ \\
\hline \multirow{4}{*}{$\begin{array}{l}\text { Adanya } \\
\text { kegiatan } \\
\text { yang } \\
\text { menarik } \\
\text { dalam } \\
\text { belajar }\end{array}$} & 16 & 50 & 60 & 31 & 37 & 3 & 3 & 0 & 0 & 84 & 100 \\
\hline & 17 & 41 & 49 & 31 & 37 & 11 & 13 & 1 & 1 & 84 & 100 \\
\hline & 18 & 25 & 30 & 42 & 50 & 16 & 19 & 1 & 1 & 84 & 100 \\
\hline & 19 & 43 & 52 & 36 & 43 & 5 & 5 & 0 & 0 & 84 & 100 \\
\hline \multicolumn{2}{|l|}{ Rata } & 40 & 48 & 34 & 40 & 9 & 11 & 1 & 1 & 84 & 100 \\
\hline
\end{tabular}

Sumber : Olah data hasil penelitian

Berdasarkan tabel di atas, menunjukkan bahwa motivasi belajar peserta didik terkait indikator adanya kegiatan yang menarik dalam belajar memiliki ratarata jawaban "sangat setuju" sebanyak 40 orang peserta didik atau sebesar 48\% dari 84 orang peserta didik, jawaban "setuju" sebanyak 34 orang peserta didik atau sebesar $40 \%$ dari 84 orang peserta didik, jawaban "kurang setuju" sebanyak 9 orang peserta didik atau sebesar $11 \%$ dari 84 peserta didik, sementara jawaban "tidak setuju" sebanyak 1 orang atau sebesar 1\% dari 84 peserta didik. Kesimpulanya untuk indikator adanya kegiatan yang menarik dalam belajar memiliki rata-rata jawaban paling banyak adalah "sangat setuju".

Gambaran motivasi belajar peserta didik MTsN 2 Bone dalam hal ini indikator adanya lingkungan belajar yang kondusif dapat dilihat pada tabel berikut:

Tabel 19 Distribusi Frekuensi Data Motivasi Belajar Peserta Didik MTsN 2 Bone untuk Indikator Adanya Lingkungan Belajar yang Kondusif

\begin{tabular}{|l|c|c|c|c|c|c|c|c|c|c|c|}
\hline Indikator & $\begin{array}{c}\text { No } \\
\text { Soal }\end{array}$ & \multicolumn{2}{|c|}{$\begin{array}{c}\text { Sangat } \\
\text { Setuju }\end{array}$} & \multicolumn{2}{c|}{ Setuju } & \multicolumn{2}{c|}{$\begin{array}{c}\text { Kurang } \\
\text { Setuju }\end{array}$} & \multicolumn{2}{c|}{$\begin{array}{c}\text { Tidak } \\
\text { Setuju }\end{array}$} & \multicolumn{2}{c|}{ Jumlah } \\
\cline { 3 - 14 } & & $\mathrm{F}$ & $\%$ & $\mathrm{~F}$ & $\%$ & $\mathrm{~F}$ & $\%$ & $\mathrm{~F}$ & $\%$ & $\mathrm{~F}$ & $\%$ \\
\hline \multirow{2}{*}{$\begin{array}{l}\text { Adanya } \\
\text { lingkungan } \\
\text { belajar yang } \\
\text { kondusif }\end{array}$} & 20 & 49 & 58 & 29 & 35 & 6 & 7 & 0 & 0 & 84 & 100 \\
\cline { 2 - 14 } & 21 & 28 & 33 & 40 & 48 & 12 & 14 & 4 & 5 & 84 & 100 \\
\cline { 2 - 13 } & 23 & 48 & 54 & 33 & 39 & 5 & 6 & 1 & 1 & 84 & 100 \\
\hline \multicolumn{2}{|c|}{ Rata-rata } & 42 & 50 & 32 & 38 & 8 & 10 & 2 & 2 & 84 & 100 \\
\hline
\end{tabular}

Sumber : Olah data hasil penelitian

Berdasarkan tabel di atas, menunjukkan bahwa motivasi belajar peserta didik terkait indikator adanya lingkungan belajar yang kondusif memiliki rata- 
rata jawaban "sangat setuju" sebanyak 42 orang peserta didik atau sebesar 50\% dari 84 orang peserta didik, jawaban "setuju" sebanyak 32 orang peserta didik atau sebesar $38 \%$ dari 84 orang peserta didik, jawaban "kurang setuju" sebanyak 8 orang peserta didik atau sebesar $10 \%$ dari 84 peserta didik, sementara jawaban "tidak setuju" sebanyak 2 orang atau sebesar $2 \%$ dari 84 peserta didik. Kesimpulanya untuk indikator adanya lingkungan belajar yang kondusif memiliki rata-rata jawaban paling banyak adalah "sangat setuju".

Berdasarkan hasil distribusi frekuensi motivasi belajar peserta didik yang di dapat dari jawaban peserta didik MTsN 2 Bone yang dilihat dari 6 (enam) indikator bahwa sebagian besar jawaban tersebut, menunjukkan peserta didik telah memiliki motivasi belajar yang baik dalam proses pembelajaran.

\section{PENUTUP}

Berdasarkan hasil penelitian dan pembahasan, maka dapat disimpulkan sebagai berikut:

1. Kompetensi kepribadian guru MTsN 2 Bone berada pada kategori sedang. Hal ini menunjukkan bahwa diantara ketiga kategori penilaian tersebut, baik itu kategori stinggi, sedang, dan rendah. Kompetensi kepribadian guru berada pada kategori sedang dengan frekuensi 10 dan persentase 55\% dengan nilai rata-rata 76,01 dari skor idel 80.

2. Motivasi belajar peserta didik MTsN 2 Bone berada pada kategori sedang. Hal ini menunjukkan bahwa diantara ketiga kategori penilaian tersebut, baik itu kategori stinggi, sedang, dan rendah. Motivasi belajar peserta didik berada pada kategori sedang dengan frekuensi 54 dengan persentase $64,30 \%$ dengan nilai rata-rata 78,55 dari skor ideal 92.

3. Terdapat pengaruh yang signifikan antara kompetensi kepribadian guru (X1) terhadap motivasi belajar peserta didik (Y) dengan nilai signifikan $\mathrm{t}$ hitung $=4.026>2.131 \mathrm{t}$ tabel, sehingga $\mathrm{H}_{0}$ ditolak dan $\mathrm{H}_{1}$ di diterima. Hasil ini, dapat dikatakan bahwa terdapat pengaruh kompetensi kepribadian guru terhadap motivasi belajar peserta didik MTsN 2 Bone. 


\section{DAFTAR PUSTAKA}

Anwar, Muhammad. Menjadi Guru Profesional. Jakarta: Kancana, 2018.

Azwar, Saifuddin. Penyusunan Skala Psikoligi. Cet. IV; Yogyakarta: Pusat Pelajar, 2013.

Dapertemen Pendidikan Nasional. Kamus Besar Bahasa Indonesia. Ed. III; Cet. II; Jakarta: Balai Pustaka, 2002.

Dauly, Haidar Putra. Pendidikan Islam dalam Sistem Pendidikan Nasional di Indonesia. Jakarta: Prenada Media, 2004.

Djamarah, Syarif Bahri. Perestasi Belajar dan Kompetensi Mengajar. Surabaya: Usaha Nasional, 2013.

Getteng, Abd. Rahman. Menuju Guru Profesional dan Ber-Etika. Cet. VIII; Yogyakarta: Graha Guru, 2012.

Kementerian Agama RI. al-Qur'ān dan Tafsirnya. Jilid 10. Cet. III; Jakarta: Dapartemen Agama RI, 2009.

Mulyasa, E. Standar Kompetensi dan Sertifikasi Guru. Bandung: PT. Remaja Rosdakarya, 2007.

Musfah, Jejen. Peningkatan Kompetensi Guru Melalui Pelatihan dan Sumber Belajar Teori dan Peraktik. Cet. II; Jakarta: Kencana, 2012.

Pusat Bahasa Depertemen Pendidikan Nasional. Kamus Besar Bahasa Indonesia. Cet. I; Jakarta: Balai Pustaka, 2001.

Republik Indonesia. Undang-Undang RI Nomor 20 Tahun 2003, tentang Sistem Pendidikan Nasional.

Republik Indonesia. Undang-Undang tentang Guru dan Dosen Nomor 14 Tahun 2005. Cet. IX; Jakarta: Sinar Grafika, 2016.

Roochman, Chaerul dan Heri Gunawan. Pengembangan Kompetensi Keperibadian Guru; Menjadi Guru yang Dicintai dan Diteladani oleh Siswa. Cet. I; Bandung: Nuansa Cendikia, 2011.

Santrock, John W. Educational Psycology, diterjemahkan oleh Tri Wibowo BS, Psikologi Pendidikan. Jakarta: Kencana, 2004.

Sommeng, Sudirman. Psikologi Umum dan Perkembangan. Makassar: Alauddin University Press, 2012.

Suprihatiningrum, Jamil. Guru Profesional Pedoman Kinerja, Kualifikasi, \& Kompetensi Guru. Cet. II; Jogjakarta: Ar Ruzz Media, 2014.

Uno, Hamzah B. Teori Motivasi dan Pengukurannya Analisis di Bidang Pendidikan. Cet. X; Jakarta: Bumi Aksara, 2013. 